\title{
Assessment of the Volta Delta Shoreline Change
}

\section{Kwasi Appeaning Addo*}

Department of Marine and Fisheries Sciences, University of Ghana, Accra, Ghana

\begin{abstract}
Shorelines fronting deltas evolve in their quest to achieve equilibrium state. Such activities have encountered the increasing human development in deltaic regions and resulted in the destruction of the environment and resources. This paper discusses the shoreline evolution trends of the Volta Delta in Ghana. The shoreline was divided into four sections based on the orientation and human interventions. Data sources for the study included satellite imageries of 1986, 1991, 2001, 2004 and 2013. Trends were statistically analysed using the AMBUR software. It emerged that the 27 years period under study, the shoreline is accreting at an average rate of about $0.53 \mathrm{~m} / \mathrm{yr}$. Section one is accreting at a rate of about $0.136 \mathrm{~m} / \mathrm{yr}$; section two is accreting a rate of about $1.703 \mathrm{~m} / \mathrm{yr}$; section three is accreting at a rate of about $2.126 \mathrm{~m} / \mathrm{yr}$; while section four is eroding at a rate of about $3.703 \mathrm{~m} / \mathrm{yr}$. This observation is significant because the area has been reported by previous studies to be eroding at a rate of about $8 \mathrm{~m} / \mathrm{yr}$. Accretion of the three sections can be explained by the presence of the Keta sea defense project (KSDP) and the shoreline orientation which influences the breaking pattern of swell waves that approach the shore. The observed development of sediment build-up will influence the sediment regime along the eastern Ghana and Togo coastal areas. There is the need to develop a systematic sub-regional coastal monitoring activity to effectively manage the coastal systems in the two countries.
\end{abstract}

Keywords: Volta delta; Cape St Paul; Coastal erosion; Ghana; Coastal management; Keta

\section{Introduction}

Delta front shorelines are active geomorphic features that are always evolving under both internal and external driving forces. Delta regions support large populations of over 500 million people globally [1], with particular concentrations in Asia and Africa. Deltas, which are highly vulnerable coastal environment due to their physical and socio-economic characteristics, are often threatened by the dynamics in the shoreline position. The changes in the shoreline positions have in most cases resulted in coastal erosion and flooding that increase the vulnerability of the low elevation deltas under changing climatic conditions. This increases the risk of pollution that pose health hazard to the delta communities and threaten food security as the farmlands get flooded. The situation results in an increasing poverty, displacement of inhabitants and forced migration that affect the local economy in most delta regions. Mapping these evolution trends enables the dynamic nature of the delta system to be determined [2]. This facilitates developing or adopting appropriate mitigation and adaptation measures to reduce the impact of the stresses. Such information also influences policy formulation at the local level that seeks to empower local governance structures in deltaic regions.

Analysis of changing trends in delta shoreline positions have been achieved by quantifying rates of linear or volumetric change within a defined domain over a period. Such changes have been calculated from time series of historical and modern shoreline positions using variety of statistical methods [3]. The single transect technique is a traditional long-term (decadal) and large-scale (hundreds of kilometers) approach that calculate shoreline statistics at closely spaced intervals along the shore [4]. This method has been used by various studies to estimate shoreline rates of change [5-7].

Single orthogonal transect calculates a shoreline rate of change at each shoreline transect using statistical methods such as End Point Rate, Average of Rates, Least Squares, Weighted Least Squares, etc. The methods fit a trend line to the time series of historical shoreline positions using a well-defined baseline that facilitates the rates of change computation. Although rate of change derived from multiple data sources introduce uncertainty in the change results that affect their reliability, the sources of errors can be identified, quantified and the results used to correct the computed rates [3,8]. Accounting for such uncertainties in the shoreline positions enable the statistical significance of the shoreline change signal to be tested, which increases the reliability in the rate of change results. Random shoreline offset, which is a major source of error in the rates of change computation, is minimised by representing the shoreline with a common indicator such as the High Water Line (HWL) proxy. The HWL, which isan important cadastral boundary that separates land and water [9], is a preferred shoreline proxy for change detection and analysis [3]. According to Graham, et al. it is the only line of contact between land and water that is identifiable on the ground at all times [10]. Various studies provide estimates of typical measurement errors associated with mapping methods and shoreline digitising [11-15].

Several studies have identified differences and similarities between the various methods of calculating shoreline rates of change $[6,16,17]$. However, extreme variations in coastal morphology and oceanographic climatology have prevented the emergence of the best methodology for calculating shoreline rates of change [18].Therefore the issue of the most appropriate method of calculating rates from shoreline position data has been subjected to considerable interest $[6,18]$. A variety of software has also been developed that incorporates the numerous statistical methods for calculating historic rate of shoreline change. These include Digital Shoreline Analysis System (DSAS) [19], SCARPS [20], Beach Tools [21]

*Corresponding author: Dr. Kwasi Appeaning Addo, Department of Marine and Fisheries Sciences, University of Ghana, Accra, Ghana, Tel: 233-242101445; E-mail: kappeaning-addo@ug.edu.gh

Received May 05, 2015; Accepted June 20, 2015; Published June 26, 2015

Citation: Addo KA (2015) Assessment of the Volta Delta Shoreline Change. J Coast Zone Manag 18: 408. doi: 10.4172/2473-3350.1000408

Copyright: (c) 2015 Addo KA. This is an open-access article distributed under the terms of the Creative Commons Attribution License, which permits unrestricted use, distribution, and reproduction in any medium, provided the original author and source are credited. 
and Analyzing Moving Boundaries Using R (AMBUR) developed by [22]. The main components of these tools define a baseline, generate orthogonal transects at a user defined separation along the coast and calculate rates of change.

The AMBUR software improves on previous shoreline analysis tools by providing functions for new transects casting techniques, detailed output from statistical analyses, generation of summary reports and graphics, and shoreline position forecasting [23]. It analyses shoreline change by capturing the positions of each historical shoreline along transects and measure changes that occur along each transect using advanced statistical analysis [22]. AMBUR provides a collection of scripts to assist with the shoreline change analysis taking advantage of R's statistical, graphical and geospatial capabilities [23]. It allows users to choose any commercial or open source GIS software for editing, preparing and viewing shape files. Along with the traditional "perpendicular" transect method used, AMBER uses two new transect methods, "near" and "filtered," which assist with quantifying changes along curved shorelines that are problematic for perpendicular transect methods. Output from the analyses using AMBUR is useful in rapidly assessing trends and potential errors in the dataset.

\section{Study area}

The coastal zone of Ghana is divided into three parts namely western, central and eastern based on the geomorphology [24]. The eastern coast represents a medium to high energy coastal environment. The Volta delta is a dominant feature in the eastern coast that has influenced the hydrodynamics and sediment regime over several decades [25]. The study area (the Volta delta), which occupies the lower portion of the Volta river basin, has been divided into four sections based on the shoreline orientation and human interventions (Figure 1). Section one is the western part of Cape St Paul covering a distance of about $18 \mathrm{~km}$; section two is around the Cape St Paul covering a distance of about $27 \mathrm{~km}$; section three is around the Keta Sea Defense Project (KSDP) site which covers a distance of about $5 \mathrm{~km}$; and section four is on the down drift side of the Keta Sea Defense Project covering a distance of about $7 \mathrm{~km}$. The study area is geographically located within latitudes $5^{0} 25^{\prime}$ and $6^{0} 20^{\prime}$ North and longitude $0^{\circ} 40^{\prime}$ and $1^{\circ} 10^{\prime}$ East. The intense hydrodynamics at the mouth of the Volta river, the relatively strong breaking waves, the considerably high energy long shore currents and the presence of submarine canyons from the shelf to the deep-water has resulted in a relatively high sediment transport in the study area $[26,27]$. The area is therefore considered as one of the highest rates of annual unidirectional long shore sand drift in the world due to the incessant wave action along the coast [28].

The Volta delta was very dynamic as a result of large sediment transport and occurrence of peak discharge before the construction of the Akosombo dam for hydroelectric power generation. The dam construction reduced the flow discharge and sediment transport significantly [24]. The river now has a regulated flow of approximately $900 \mathrm{~m}^{3} / \mathrm{s}$ and sediment discharge has reduced from about 71 million $\mathrm{m}^{3} /$ yr to about 7 million $\mathrm{m}^{3} / \mathrm{yr}$ [25]. The situation has resulted in increased coastal erosion, which displaced about five hundred people within a period of twenty years [24]. It is estimated that over two-thirds of the study area is potentially at risk of increased erosion and flooding due to climate change associated sea level rise [29-32]. Presently, sea level rise is about $3 \mathrm{~mm} / \mathrm{yr}[3,33]$ which is predicted to change in conformity to the global trend [34].

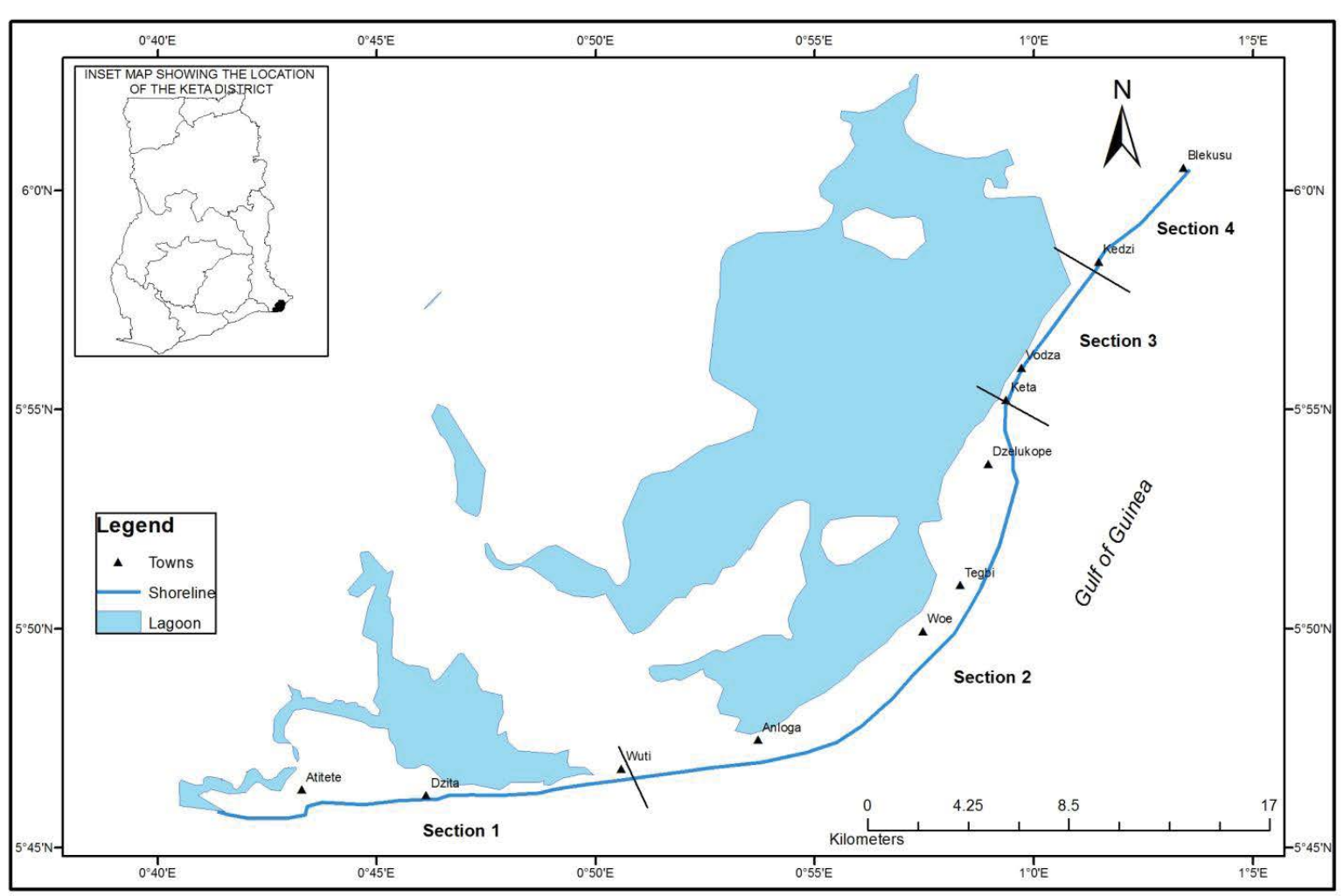

Figure 1: Map of the study area showing the four sections. 
Geologically, the study area has soft quaternary rocks and unconsolidated sediments of clay, loose sand and gravel deposits [31]. Relatively large portion of the landscape is characterised by the Keta Lagoon complex, the Songorlargoon, a number of creeks along the coast as well as vast marshy areas. The large wetlands in the study area is designated a Ramsar site [31]. The Keta lagoon, which is the largest lagoon in Ghana, is separated from the sea by a sandbar (sand spit). The sandbar is narrow, barely more than $2.5 \mathrm{~km}$ at its widest point with a general elevation of up to $2 \mathrm{~m}$ above mean sea level [35]. The near shore area is fronted by a moderately steep upper shore face with a gradient of between 1:20 and 1:50 down to the $10 \mathrm{~m}$ isobaths [28]. Two main types of wave approach this coast. They include seas generated by weak local monsoon and swells generated by storms in the southern part of the Atlantic Ocean. Tides are semi-diurnal with a tidal range of about $1 \mathrm{~m}$ which generates weak tidal currents [26]. The climate is dry equatorial. The vegetation normally comprises of coastal strands and mangrove. Similar to the entire coastal zone of Ghana, the study area experiences two rainy seasons. The main rainy season is between May and July with a minor one between late August and early October while November to April is the dry season [35]. The monthly average wind speed along the coast ranges between 1.7 and $2.6 \mathrm{~m} / \mathrm{s}$ [36].

\section{Methodology}

Division of the study area into four sections enabled the shoreline evolution trends to be analysed for the sections using the orthogonal transect method. Data for the study included satellite imageries for 1986, 1991, 2001, 2007, 2013 (Table 1). The images were acquired from the United States Geological Survey, Earth Resources Observation and Science Centre. The Landsat TM data were resampled to $15 \mathrm{~m}$ resolution to ensure compatibility with the ASTER data. The Landsat ETM+ panchromatic data with a resolution of $15 \mathrm{~m}$ was used to sharpen the six multispectral bands to obtain a new image at $15 \mathrm{~m}$. The Landsat images, which were acquired at level L1T, have absolute geodetic accuracy.

The ASTER data was obtained in the raw state. Geometric correction/rectification was therefore carried out on the data. The Gram-Schmidt pan sharpening algorithm in ENVI which is based on principal component analysis was used. The images were co-registered to the Landsat $2001 \mathrm{ETM}+$ data using 30 visually interpreted Ground Control Points (GCP). The GCPs were used to warp and resample the ASTER image using first order polynomial and nearest neighbour transformation. The total root mean square (RMS) error was $0.35 \mathrm{~m}$ which was less than the pixel size of the imageries hence less critical in accounting for overall positional error. This gave confidence in using the data for the rate of change analysis. The Landsat ETM+ was used for the co-registering process because its validity had been ascertained by [31]. Again, field identification of some selected GCPs such as road intersections and landmark structures enabled ground measurement of their coordinates using handheld GPS (eTrex Vista H). The results were plotted on the imageries to check their positional accuracy, which further increased confidence in the reliability of the data. The high waterline (HWL), which is used as shoreline proxy in Ghana [3] was

\begin{tabular}{|c|c|c|}
\hline Data & Acquisition date & Resolution \\
\hline Landsat TM & $1986-01-13$ & $30 \mathrm{~m}$ \\
\hline Landsat TM & $1991-01-03$ & $30 \mathrm{~m}$ \\
\hline Landsat ETM+ & $2001-01-30$ & $30 \mathrm{~m}, 15 \mathrm{~m}$ \\
\hline Landsat 8 & $2013-08-03$ & $30 \mathrm{~m}, 15 \mathrm{~m}$ \\
\hline ASTER & $2007-11-06$ & $15 \mathrm{~m}$ \\
\hline & Table 1: Data sources. \\
\end{tabular}

adopted as the shoreline position. The imageries were taken during the high water time to ensure compatibility and facilitate change detection. The HWL were extracted using both semiautomatic and manual methods.

The water-land boundary was identified using band ratio between the mid infrared (band 5 [b5]) and the green (band 2 [b2]) for the Landsat data. This reduced the level of subjectivity in delineating the shoreline. Band ratio was implemented using the band ratio model in the ENVI software (thus $\mathrm{b} 5 / \mathrm{b} 2$ ). The resultant image with ratio values between 0 and 3 was sliced and segmented to form a binary image. Values less than 1 were classified as water and values greater than 1 were classified as land. This standard facilitated the delineation of the boundary between water and land. Separation ratio of 1 has been successfully used in other studies $[37,38]$. The water class was then converted from raster to vector and exported as shape files for overlay in ArcMap. The output vector however consisted of other water/land boundaries such as those of creeks and lagoons and could not be directly used for change analyses. To extract the target shorelines, the extracted vector shorelines were overlaid on the colour composites and used as a guide in the digitizing process. The ASTER image was however directly digitized. The digitized shorelines were then grouped and prepared for the rates of change computations.

\section{Uncertainty quantification}

Sources of uncertainty in the computed rates of change include the variability of actual behaviour of the shoreline due to seasonal changes; data manipulations in ArcMap such as digitising of the shoreline position, overlay of multiple layers and inconsistency in non-linear information (metadata); and the use of linear regression in AMBUR to compile the shoreline position. The HWL proxy was used to represent the shoreline positions on all the data and a common datum (Clarke 1880 ellipsoid) as well as projection (Transverse Mercator) were used for the entire shoreline mapping that reduced uncertainty as a result of data compatibility and manipulation in ArcMap. However, uncertainties associated with the shoreline data capture were quantified based on [15] since they will have significant effect on the positional accuracy of the shoreline extracted. The major source of error for this analysis was the resolution $(15-30 \mathrm{~m})$. The generally accepted estimates from sources such as digitizing, image registration, tide and shoreline position were less than the pixel size, therefore were negligible. A total shoreline positional error for each shoreline position was estimated at $15 \mathrm{~m}$. The values were annualised to provide error estimation for the shoreline change rate at any given transect and expressed as:

$$
E_{a}=\sqrt{\left(E_{1}{ }^{2}+E_{2}{ }^{2}+E_{3}{ }^{2}+E_{4}{ }^{2}+E_{5}{ }^{2}\right) / T}
$$

Where $E_{1}, E_{2}, \ldots E_{5}$ are the total shoreline position error for the various years and $T$ is the 27 years period of analysis. The maximum annualised uncertainty using best estimate for this study is $\pm 1.24 \mathrm{~m} /$ year.

\section{Analyzing historic shoreline rates of change}

Historic rates of change were analysed using the AMBUR software. The AMBUR software was adopted because of the advantages it has over other methods. The digitized five shoreline proxies were appended in ArcGIS environment into a single shapefile. A baseline was also digitized by mimicking the outer shoreline and saved as a shapefile. Both the shoreline and the baseline shapefiles were uploaded in AMBUR and their attribute fields populated to satisfy conditions for the software. The positional accuracy of the shoreline was set as $1 \mathrm{~m}$ based on [3]. Perpendicular transects were automatically cast at $50 \mathrm{~m}$ intervals from the baseline across the appended shoreline. Although 
studies by [39], identified that transect spacing below $100 \mathrm{~m}$ does not result in improved estimates of shoreline change rate, however shorter intervals enable more details to be included in the rates of change estimation which reduces uncertainties. Transect orientations were filtered to reduce gaps between the endpoints of transects and better approximate the curvature of the baselines. Confidence level was set at $95 \%$ to compute error bars in the linear regression statistics.

\section{Results}

The merged different date shoreline positions in the study area indicate that the Volta delta front shoreline is undergoing significant lateral changes. A total of 1124 transects were generated. It emerged that 571 transects were eroding while the remaining 553 were either accreting or stable for the 27 year period under study. The oldest and youngest date shoreline positions were 1986 and 2013 respectively. The End Point Rate method of estimating erosion rates of change for the oldest and the youngest shoreline positions indicate varying trend of erosion and accretion along the coast (Figure 2). The mean erosion rate was $-1.86 \mathrm{~m} / \mathrm{yr}$ while the mean accretion rate was $+3.00 \mathrm{~m} / \mathrm{yr}$. The overall mean change rate was $+0.53 \mathrm{~m} / \mathrm{yr}$ for the 27 years under study. Analysis of the four sections along the coast indicates that they have evolved within the 27 year period. Section one is accreting at a rate of about $+0.136 \mathrm{~m} / \mathrm{yr}$; section two is accreting a rate of about $+1.703 \mathrm{~m} / \mathrm{yr}$; section three is accreting at a rate of about $+2.126 \mathrm{~m} / \mathrm{yr}$; while section four is eroding at a rate of about $-3.703 \mathrm{~m} / \mathrm{yr}$.

A graph of cumulative change for 1986 - 1991, 1991 - 2001, 2001 - 2007, and 2007 - 2013 is shown in Figure 3 where colours blue and red indicate accretion and erosion respectively. It reveals the pattern of change in the shoreline positions for the various years.

Change statistics was also determined for the various eras. It emerged from analysis of the 1986 and 1991 shoreline positions that 634 transects out of the total transect of 1124 eroded while the remaining 490 transects accreted (Figure 4). The estimated mean erosion rate was $-5.78 \mathrm{~m} / \mathrm{yr}$ and the mean accretion rate was $23.08 \mathrm{~m} / \mathrm{yr}$.

The period between 1991 and 2001 shoreline change analysis revealed that 792 transects eroded while the remaining 332 transects accreted within the 10 year period (Figure 5). The estimated mean erosion rate was $-6.47 \mathrm{~m} / \mathrm{yr}$ and the estimated accretion rate was 4.21 $\mathrm{m} / \mathrm{yr}$.

Estimation of shoreline change between 2001 and 2007 using the EPR method revealed that 210 transects eroded and the remaining 913 accreted (Figure 6). The computed mean erosion rate was $-5.02 \mathrm{~m} / \mathrm{yr}$ while the mean accretion rate was $+11.52 \mathrm{~m} / \mathrm{yr}$.

It emerged from analysis of the period between 2007 and 2013 that 953 transects eroded while the remaining 170 accreted (Figure 7 ). The mean erosion rate was $-8.38 \mathrm{~m} / \mathrm{yr}$ while the mean accretion rate was $+6.26 \mathrm{~m} / \mathrm{yr}$.

\section{Discussions}

The Volta delta front shoreline is undergoing varying intensities of changes. This can be attributed to both natural and human induced driving forces. The mean shoreline rate of change over the 27 years under study was $+0.53 \mathrm{~m} / \mathrm{yr}$, which indicates accretion. The mean erosion rate was $-1.86 \mathrm{~m} / \mathrm{yr}$ while the mean accretion rate was +3.00 $\mathrm{m} / \mathrm{yr}$. This indicates a significant reduction in erosion rate estimated by [24]. Ground-truthing of the observed trend through critical field observation of locations with significant changes and informal interaction with the inhabitants confirmed the observed trend. The observed trend can be attributed to natural factors such as wave and tidal actions, the shoreline orientation, the near shore bathymetry and the nature of the prevailing rocks; and anthropogenic activities such as the Keta Sea Defense Project (KSDP). The project combined hard (revetment and groynes) and soft engineering (beach fill) methods to restore and stabilize the shoreline in Keta. The shoreline was eroding at a rate of between 4-8 m/year [24]. Erosion destroyed infrastructure, collapsed sources of livelihood of the inhabitants and led to migration of people from the communities [24]. The six well-spaced $200 \mathrm{~m}$ long groynes constructed alongshore continue to trap sediment which is building the beach. This confirms observations by [31]. The observed recession trend will influence the shoreline on the eastern coast of Ghana as well as the western coast of Togo. The gradual building-up of sediment will affect the sediment budget in the coastal system and facilitate beach nourishment in the coastal zone.

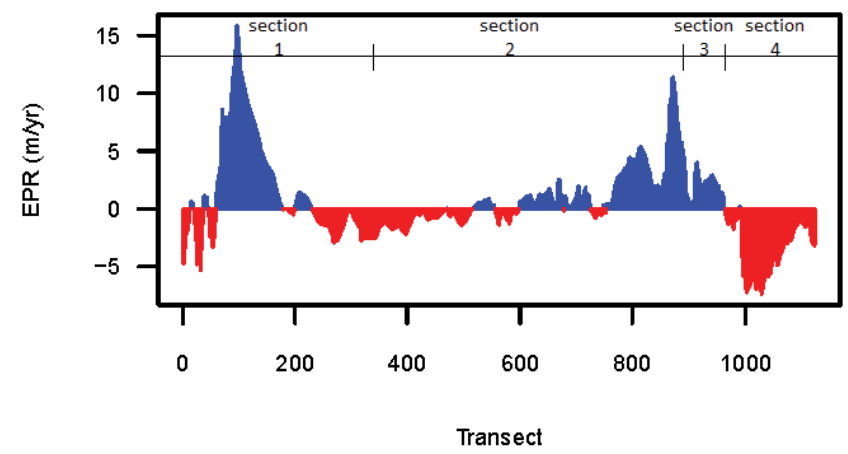

Figure 2: Graph of rates of change between 1986 and 2013 using the EPR method.
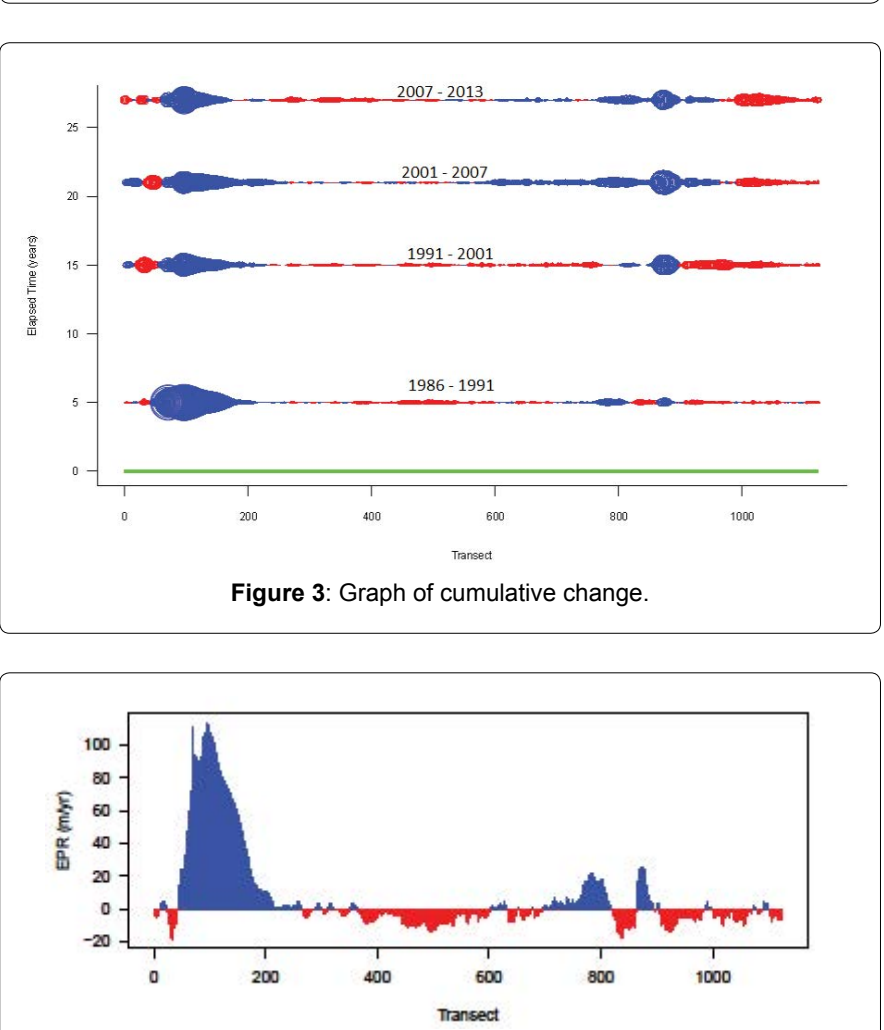

Figure 4: EPR of change for 1986 to 1991. 


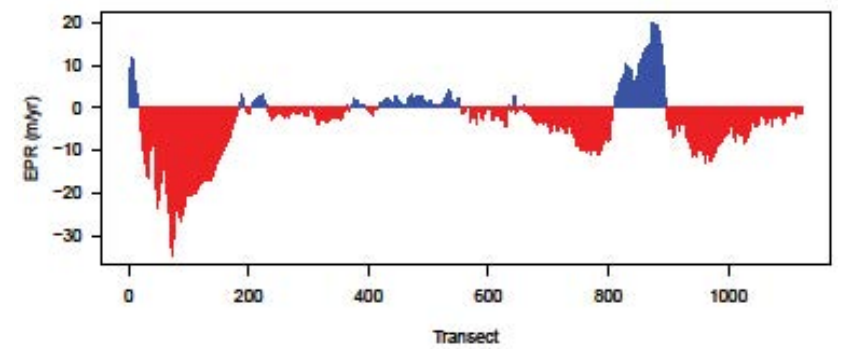

Figure 5: EPR of change for 1991 to 2001.

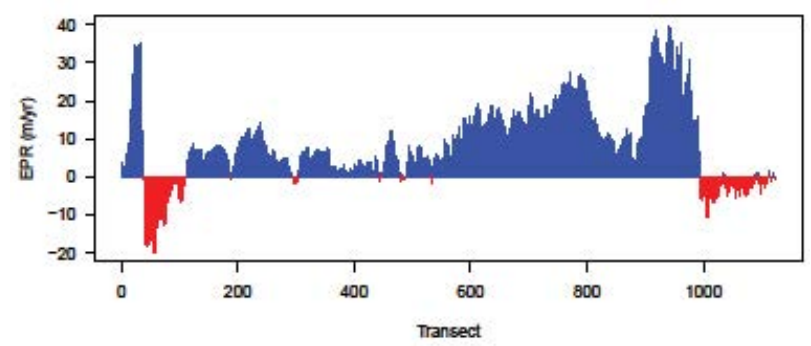

Figure 6: EPR of change for 2001 to 2007.

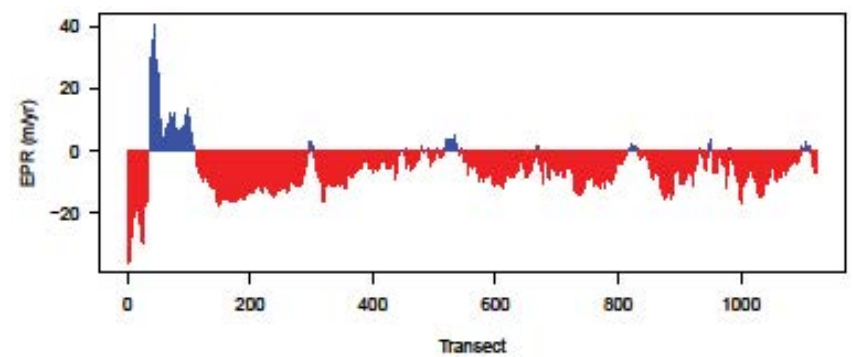

Figure 7: EPR of change for 2007 to 2013.

The changing trend observed varied in the four sections. The shorelines in sections one, two and three accreted at different rates. However, the shoreline in section four eroded at a relatively high rate. The results obtained for section one confirms observation by [40]. Their study identified increasing mangroves cover along that section of the coast and concluded that sediment build-up in part account for their observation. The direction of sediment transport is from west to the east along the coast [41]. Trend analysis of shoreline change between 1986 and 1991 and between 1991 and 2001 (before the KSDP) indicate relatively high erosion in sections two and three. The period between 2001 and 2007 (post KSDP) showed increased accretion trend in sections two and three. However, the period between 2007 and 2013 (post KSDP) revealed a reversed trend of erosion. This could be due to the system dynamics attaining a form of equilibrium. The trend observed in section four confirms studies by [29] and [25] that identified increased erosion on the down-drift side of the KSDP. Although the groynes continue to trap sediment to build the beach, they starve the down-drift side of sediment. The results revealed the vulnerable state of the delta environment, especially the down-drift side of the KSDP, and the impact of increased erosion on the socioeconomic life of the inhabitants. Although previous studies by [29] and [25] have discussed the negative impact of using groynes to manage erosion in Keta, the groynes are a major factor in the observed trend of accretion in sections one, two and three. It is also conceivable that sediment from offshore is also influencing the sediment budget in the study area.

\section{Conclusion}

The Volta delta front shoreline has evolved over the 27 years period under study. The pre and post KSDP periods indicate reversing trends from high erosion to accretion. This indicates that the KSDP has been successful. It has resulted in building the beaches along portions of the coast. This notwithstanding, the groynes have also increased erosion on the down-drift side of the KSDP. This threatens the coastal inhabitants and has increased vulnerability along the coast. The situation if not effectively managed can increase poverty and migration as sources of livelihood are destroyed. However, gradual accumulation of sediment along the up-drift side of the groyens will influence the sediment budget in the coastal system. This will positively affect the coast of eastern Ghana and Togo as the shoreline orientation will enable the sediment build-up to nourish the beaches. It is recommended that a joint coastal monitoring scheme at the sub-regional level should be set up between Ghana and Togo to further study the dynamics of the observed shoreline changing trend and the sediment build-up.

\section{References}

1. Woodroffe CD, Nicholls RJ, Saito Y, Chen ZY, Goodbred SL (2006) Landscape variability and the response of asian megadeltas to environmental change. In: N. Harvey (ed.) Global change and integrated coastal management:The asia-pacific region. Springer Netherlands 277-314.

2. Kundu S, Mondal A, Khare D, Mishra P, Shukla R (2014) Shifting shoreline of Sagar Island delta in India. Journal of maps 10: 612-619.

3. Appeaning Addo K, Walkden M, Mills JP (2008) Detection, Measurement and Prediction of Shoreline Recession in Accra, Ghana. ISPRS Journal of Photogrammetry and Remote Sensing 63: 543-558.

4. Anderson TR, Frazer LN, Fletcher CH (2014) Long-Term Shoreline Change at Kailua, Hawaii, Using Regularized Single Transect. Journal of Coasta Research 31: 464-476.

5. Fletcher $\mathrm{CH}$, Rooney JJB, Barbee M, Lim SC, Richmond BM (2003) Mapping Shoreline Change Using Digital Orthophotogrammetry on Maui, Hawaii. Journal of Coastal Research 38: 106-124.

6. Genz AS, Fletcher CH, Dunn RA, Frazer LN, John J. Rooney JJ (2007) The Predictive Accuracy of Shoreline Change Rate Methods and Alongshore Beach Variation on Maui, Hawaii. Journal of Coastal Research 23: 87-105.

7. Theiler ER, Himmelstoss EA, Zichichi JL, Miller TL (2005) Digital Shoreline Analysis System (DSAS) version 3.0; An ArcGIS extension for calculating shoreline change. U.S. Geological Survey Open-File Report 2005-1304.

8. Fang Y, Christopher EP, Shachak P, Brian RC, Yuri R (2015) Modeling Uncertainty in Photogrammetry-Derived National Shoreline. Marine Geodesy 38: 128-145.

9. Liu X, Xia JC, Wright G, Arnold L (2014) A state of the art review on High Water Mark (HWM) determination. Ocean \& Coastal Management 102: 178190.

10. Graham D, Sault M, Bailey JC (2003) National Ocean Service shoreline Past, Present, and Future. Journal of Coastal Research 38: 14-32.

11. Crowell M, Letherman SP, Buckley MK (1991) Historical Shoreline Change: Error Analysis and Mapping Accuracy. Journal of coastal research 7: 839852.

12. Theiler ER, Danforth WW (1994) Historical Shoreline Mapping (II): Application of the Digital Shoreline Mapping and Analysis Systems (DSMS/DSAS) to Shoreline Change Mapping in Puerto Rico. Journal of Coastal Research 10: 600-620.

13. Moore LJ (2000) Shoreline Mapping Techniques. Journal of Coasta Research 16: 111-124. 
14. Morton RA, Miller TL, Moore LJ (2004) National assessment of shoreline change: Part 1: Historical Shoreline Changes and Associated Coastal Land Loss along the U.S. Gulf of Mexico. U.S. Geological Survey Open-file Report.

15. Hapke CJ, Himmelstoss EA, Kratzman MG, List JH, Thieler ER (2010) National Assessment of Shoreline Change: Historical Shoreline Change along the New England and Mid-Atlantic Coasts. U.S. Geological Survey, Open-File Report 57.

16. Crowell M, Douglas BC, Leatherman SP (1997) On Forecasting Future US Shoreline Positions: A Test of Algorithms. Journal of Coastal Research 13: 1245-1255.

17. Zuzek PJ, Nairn R, Thieme SJ (2003) Spatial and Temporal Considerations for Calculating Shoreline Change Rates in the Great Lakes Basin. Journal of coastal research 38: 125-146.

18. Honeycutt MG, Krantz D (2002) Shoreline Change along Delaware's Atlantic Coast: Analyses of Spatial Variability and Erosion-Forecast Uncertainty. Shoreline Change Conference Proceedings NOAA Coastal Services Centre Session IV.

19. Theiler ER, Himmelstoss EA, Zichichi JL, Ayhan E (2009) Digital Shoreline Analysis System (DSAS) version 4.0-An ArcGIS extension for calculating shoreline change: U.S. Geological Survey Open-File Report 2008-1278.

20. Jackson CW (2009) Assessing historical shoreline changes and erosion hazards using tools developed for ArcGIS and R. In: Proceedings of the NOAA Coastal GeoTools 2009 Conference Program 102.

21. Hoeke RK, Zarillo GA, Synder M (2001) A GIS based tool for extracting shoreline positions from aerial imagery (BeachTools). Coastal and Hydraulics Engineering Technical Note CHETN-IV-37, US Army Engineer Research and Development Center, Vicksburg, MS.

22. Jackson CW (2010) Basic user guide for the AMBUR package for R, version 1.0a.

23. Jackson CW, Alexander CR, Bush DM (2012) Application of the AMBUR $R$ package for spatio-temporal analysis of shoreline change: Jekyll Island, Georgia, USA. Computers \& Geosciences 41: 199-207.

24. Ly CK (1980) The role of the Akosombo Dam on the Volta River in Causing Erosion in Central and Eastern Ghana (West Africa). Mar Geol 37: 323 - 332.

25. Boateng I (2009) Development of Integrated Shoreline Management Planning: A Case Study of Keta, Ghana. Proceedings of the International Federation of Surveyors Working Week, May 3rd-8th, Eilat, Israel 1-19.

26. Wellens-Mensah J, Armah AK, Amlalo DS, Tetteh K (2002) Ghana National Report Phase 1: Integrated Problem Analysis. GEF MSP Sub-Saharan Africa Project (GF/6010-0016): Development and Protection of the Coastal and Marine Environment in Sub-Saharan Africa. Accra, Ghana.

27. Manu T, Botchway IA, Apaalse LA (2005) Petroleum Exploration Opportunities in the Keta Area. The Volta Monitor 1: 56-57.
28. Anthony EJ, Blivi AB (1999) Morphosedimentary evolution of a delta-sourced, drift-aligned sand barrier-lagoon complex, western Bight of Benin. Marine geology 158: 161-176.

29. Angnuureng BD, Appeaning Addo K, Wiafe G (2013) Impact of sea defense structures on downdrift coasts: The case of Keta in Ghana. Academia Journal of Environmental Science 1: 104-121.

30. EPA (2003) Information for Africa Climate Technology Transfer (IACTT).

31. Jayson-Quashigah PN, Appeaning Addo K, Kufogbe SK (2013) Shoreline monitoring using medium resolution satellite imagery, a case study of the eastern coast of Ghana. Journal of Coastal Research. 65: 511-516.

32. Wiafe G, Boateng I, Appeaning Addo K, Quashigah PN, Ababio SD, et al (2013) Handbook of Coastal Processes and Management in Ghana. The Choir Press. 274

33. Sagoe-Addy K, Appeaning Addo K (2013) Effect of predicted sea level rise on tourism facilities along Ghana's Accra coast. Journal of Coastal Conservation and Management 17: 155-166.

34. Armah AK, Wiafe G, Kpelle DG (2005) Sea-Level Rise and Coastal Biodiversity in West Africa: A Case Study from Ghana, in Climate Change and Africa 204-217.

35. Awadzi TW, Ahiabor E, Breuning-Madsen H (2008) The Soil-Land Use System in a Sand Spit Area in the Semi-arid Coastal Savannah region of Ghana- Development, Sustainability and Threats. West African Journal of Ecology 13: 132-143

36. Sorensen TH, Volund G, Armah AK, Christensen C, Jensen IB, et al. (2003) Temporal and spatial variations in concentrations of sediment nutrients and carbon in the Keta lagoon, Ghana. West Afr J appl Ecol 4: 91-105.

37. Guariglia A, Buonamassa A, Losurdo A, Saladino R, Trivigno ML, et al. (2006) A multisource approach for coastline mapping and identification of shoreline changes. Annals of Geophysics 49: 295-304.

38. Kuleli T (2010) Quantitative analysis of shoreline changes at the Mediterranean Coast in Turkey. Environmental monitoring and assessment 167: 387-397.

39. Doukakis E (2004) Transect Spacing and Coastal Evolution, 3rd International Energy, Energy and Environmental Symposium.

40. Manson Awo Akosua Boatemaa, Apppeaning Addo Kwasi, Adelina Mensah (2013) Impacts of Shoreline Morphological Change and Sea Level Rise on Mangroves: the Case of the Keta Coastal Zone. E3 Journal of Environmental Research and Management 4: 0334-0343.

41. Appeaning Addo Kwasi (2014) Managing Shoreline Change under Increasing Sea Level Rise in Ghana. Coastal Management 42: 555-567. 